\title{
Epidemiology of columnaris disease affecting fishes within the same watershed
}

\author{
Haitham H. Mohammed, Covadonga R. Arias* \\ Aquatic Microbiology Laboratory, School of Fisheries, Aquaculture and Aquatic Sciences, 203 Swingle Hall, \\ Auburn University, Auburn, Alabama 36849, USA
}

\begin{abstract}
In the southeastern USA, columnaris disease (caused by Flavobacterium columnare) typically affects catfish raised in earthen ponds from early spring until late summer. Recently, unusually severe outbreaks of columnaris disease occurred at the E. W. Shell Fisheries Center located in Auburn, AL, USA. During these outbreaks, catfish and other aquaculture and sport fish species that were in ponds located within the same watershed were affected. Our objective was to investigate the genetic diversity among $F$. columnare isolates recovered from different sites, sources, and dates to clarify the origin of these outbreaks and, ultimately, to better understand the epidemiology of columnaris disease. A total of $102 \mathrm{~F}$. columnare isolates were recovered from catfishes (channel catfish Ictalurus puntactus, blue catfish I. furcatus, and their hybrid), bluegill Lepomis microchirus, Nile tilapia Oreochromis niloticus, largemouth bass Micropterus salmoides, egg masses, and water during columnaris outbreaks (from spring 2010 to summer 2012). Putative F. columnare colonies were identified following standard protocols. All isolates were ascribed to Genomovar II following restriction fragment length polymorphism analysis of the 16S rRNA gene. Genetic variability among the isolates was revealed by amplified fragment length polymorphism. Date of isolation explained most of the variability among our isolates, while host was the least influential parameter, denoting a lack of host specificity within Genomovar II isolates. The susceptibility of each of the isolates against commonly used antibiotics was tested by antibiogram. Our data showed that 19.6 and $12.7 \%$ of the isolates were resistant to oxytetracycline and kanamycin, respectively.
\end{abstract}

KEY WORDS: Flavobacterium columnare - Epidemiology · Columnaris disease • Antibiotic resistance $\cdot$ AFLP

Resale or republication not permitted without written consent of the publisher

\section{INTRODUCTION}

Columnaris disease is an acute to chronic bacterial infection that affects a variety of freshwater fishes, including commercially important species worldwide (Austin \& Austin 1999, Plumb 1999, Soto et al. 2008, Suomalainen et al. 2009). Flavobacterium columnare, the causal agent of columnaris disease, is a Gramnegative bacterium, ubiquitous in aquatic environments. In the southeastern USA, columnaris disease is the second most prevalent bacterial infection in channel catfish Ictalurus punctatus after enteric septicemia of catfish (ESC) caused by the bacterium
Edwardsiella ictaluri. Recently, a summary of cases compiled from 2001 to 2012 by the Aquatic Research and Diagnostic Laboratory, Mississippi State University (MSU 2010, 2012), reported F. columnare as the most frequently diagnosed pathogen in catfish farms.

Several factors have been suggested to influence the susceptibility of fish to $F$. columnare infection, although limited information is available from field studies. Some of these predisposing factors have been used to induce acute columnaris disease under experimental conditions, including skin abrasions (Bader et al. 2003, 2006), feed deprivation (Shoemaker et al. 2003), static challenge water (Thomas- 
Jinu \& Goodwin 2004a), high stocking densities (Wakabayashi 1991, Iguchi et al. 2003, Suomalainen et al. 2005), and temperature stress (Wakabayashi 1991, Decostere et al. 1999, Thomas-Jinu \& Goodwin 2004b, Suomalainen et al. 2005). However, columnaris disease outbreaks can occur without any stressor (Plumb 1999).

Besides environmental factors, the severity of columnaris disease is greatly influenced by the genetic type of the strain causing the infection (Shoemaker et al. 2008). F. columnare is a phenotypically homogeneous species but harbors a large degree of genetic diversity. Three different genetic groups or genomovars have been described within the species, and all of them have been isolated from diseased fish in the USA (Triyanto \& Wakabayashi 1999, Arias et al. 2004, Thomas-Jinu \& Goodwin 2004b, Darwish \& Ismaiel 2005, Olivares-Fuster et al. 2007b). Recently, LaFrentz et al. (2013) refined the protocol for typing $F$. columnare isolates using restriction fragment length polymorphism (RFLP) of the 16S rRNA gene and formally described the restriction patterns for the previously described Genomovars I, II, II-B, and III (Olivares-Fuster et al. 2007b) and described a new genomovar, I/II. Many virulence studies have shown that Genomovar II strains are more virulent than Genomovar I strains in channel catfish (Shoemaker et al. 2008, Soto et al. 2008), blue catfish, and their hybrid (Arias et al. 2012) as well as in zebrafish Danio rerio (Olivares-Fuster et al. 2011) and rainbow trout Oncorhynchus mykiss (LaFrentz et al. 2012). Ascription to genomovar using 16S-RFLP is easy to perform and is a good indicator of strain virulence. However, for molecular epidemiology studies, a higher resolution method is needed in order to unveil the intraspecies genetic diversity. Among all the typing methods used to describe the genetic diversity in $F$. columnare, amplified fragment length polymorphism (AFLP) has one of the highest indices of discriminatory power ( $\mathrm{D}=0.949$ ) (Olivares-Fuster et al. 2007b). AFLP analyzes nucleotide positions distributed over the whole genome and thus is likely to find more polymorphisms than techniques screening for just a few loci. AFLP can detect polymorphisms more efficiently than other DNA technologies, such as RFLP, random amplified polymorphic DNA (RAPD), and microsatellite or simple sequence repeat polymorphism (SSR) analysis (Miyashita et al. 1999).

Currently, preventive measures against columnaris disease are limited. Proper husbandry and health management practices are crucial to prevent $F$. columnare infections (Decostere 2002, Farmer 2004, Declercq et al. 2013b). However, after disease onset, the use of therapeutants, primarily antibiotics, is necessary to reduce high mortalities associated with the disease. The repetitive application of antibiotics to any animal production system is linked with a higher incidence of antibiotic-resistant bacteria. This has already been detected in both of the fish pathogens F. psychrophilum (Ekman 2003) and F. columnare (Declercq et al. 2013a). Moreover, the discharge of even small quantities of antibiotics into the environment can lead to the emergence of drug-resistant strains in environmental bacterial communities resulting from lateral transfer of these resistant traits between bacterial species (Schmidt et al. 2000, Serrano 2005, Miranda \& Rojas 2007).

Despite best management practices, the incidence and severity of columnaris disease outbreaks in aquaculture have not decreased worldwide. On the contrary, columnaris disease prevalence in commercial rainbow trout farming in Idaho, USA (S. E. LaPatra pers. comm.), has increased in recent years (LaFrentz et al. 2012). Similarly, in Finland, columnaris outbreaks were first reported in the early 1990s and have increased annually to the point of seriously threatening the Finnish fish farming industry (Suomalainen 2005). The southeastern USA concentrates the vast majority of USA aquaculture production (focused on channel catfish), where columnaris disease is considered endemic. Despite columnaris disease impacts on the industry, few studies have analyzed in depth the epidemiology of this disease (Soto et al. 2008). Recently, severe epizootics of columnaris disease occurred at the E. W. Shell Fisheries Center (EWSFC) at Auburn, AL, USA. These outbreaks affected both aquaculture and sport fish species in ponds located within the same hydrologic unit from spring 2010 till summer 2012. The objective of this study was to investigate the intraspecific genetic diversity among $F$. columnare isolates collected during these outbreaks to better understand columnaris disease epidemiology in open aquaculture systems. In addition, we wanted to investigate the antibiotic susceptibility patterns of these isolates to determine the antimicrobial agent of choice for treatment during columnaris outbreaks.

\section{MATERIALS AND METHODS}

\section{Sampling sites}

The EWSFC is located in Auburn, AL, USA $\left(32^{\circ}\right.$ $40^{\prime} \mathrm{N}, 85^{\circ} 30^{\prime} \mathrm{W}$ ), and comprises approximately $6.5 \mathrm{~km}^{2}$ of which $1 \mathrm{~km}^{2}$ is surface water distributed in ponds 
that range in size from $400 \mathrm{~m}^{2}$ to $105500 \mathrm{~m}^{2}$. Water is collected from rainfall on watersheds surrounding the ponds. Water flows by gravity north to south, and most of the ponds, as well as the research buildings, are connected by permanent or intermittent water flows (Fig. 1). In addition, heavy rainfall events, birds, vehicles, and seining equipment facilitate the transfer of pathogens between ponds. For the purpose of this study, we considered all ponds and buildings at the EWSFC to be part of the same watershed. Two additional sampling locations situated on the main campus (10 km south of EWSFC) were included in the study but were not hydrologically linked with the EWSFC.

\section{Samples}

Unusually high mortalities due to columnaris disease occurred at the EWSFC in 2010, 2011, and 2012. Moribund fish showing signs of columnaris disease were sampled using standard protocols for isolation of Flavobacterium columnare (Thoesen 2004). In 2010, columnaris disease affected channel catfish fingerlings and tilapia stocked in ponds located at the south end of the EWSFC. These samples were labeled as LS (lower station). In 2011, columnaris disease affected channel catfish fry at the hatchery. Samples were taken from fry, water, and egg masses from spawning tanks. All samples collected at the hatchery were labeled as HA. Some egg masses were transported to the School of Veterinary Medicine, Auburn University, located on the main campus, where they were disinfected upon arrival using $100 \mathrm{ppm}$ iodine solution for $10 \mathrm{~min}$. After hatching, most of the fry were lost due to columnaris disease. Samples were collected from moribund fry and recorded as VS (Vet School). In 2012, columnaris disease affected large ponds at the upper station. High mortalities in sport fishing ponds (S1, S3, and S6 stocked with bluegill and largemouth bass) occurred from April till August (the percentage of fish that succumbed to the infection could not be estimated; it was the highest mortality observed in those ponds within the last $15 \mathrm{yr}$; R. Wright, Auburn University, pers. comm.). Typical columnaris disease signs (i.e. 'saddleback' lesions, skin discoloration, and gill necrosis) were observed in dead and moribund bluegill and largemouth bass. Channel, blue, and hybrid catfish reared in raceways using water from the affected S1 pond also succumbed to columnaris along with hybrid and channel catfish stocked in Ponds S10 and S11. During the summer of 2012, columnaris dis-

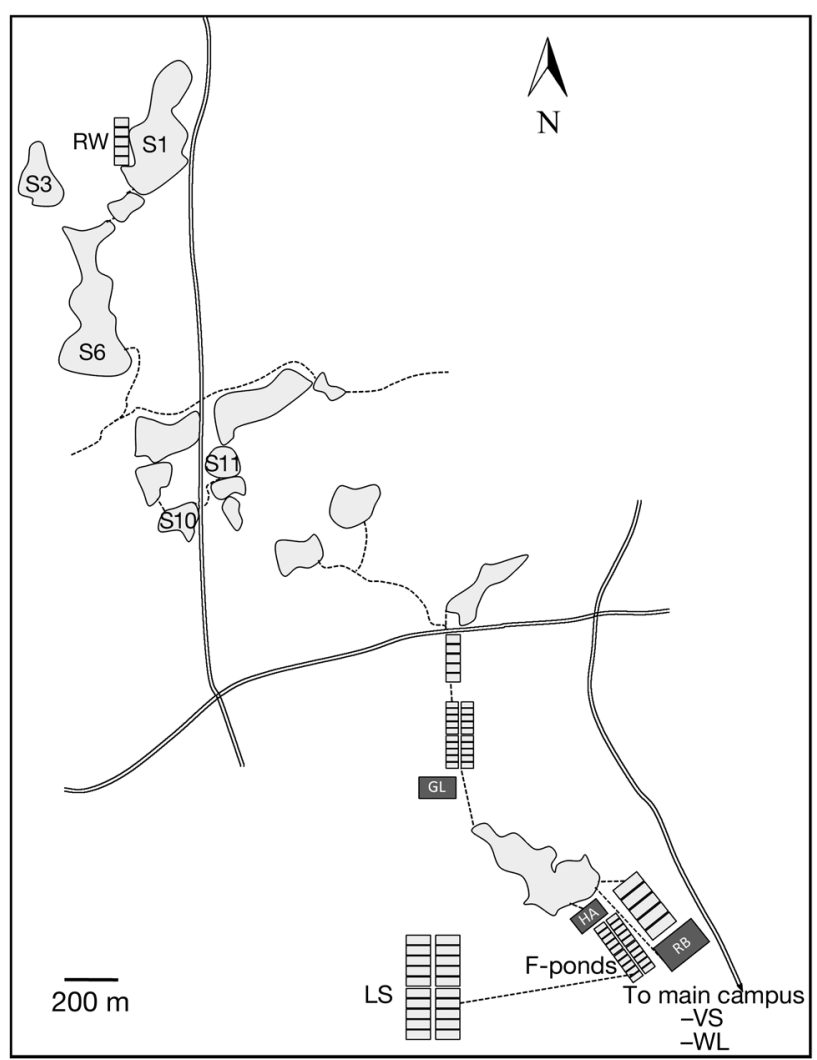

Fig. 1. E. W. Shell Fisheries Center showing relative positions of upper ponds (S1, S3, S6, S10, and S11), raceways (RW), genetics unit (GL), and lower station (HA: hatchery; RB: research building; LS: other lower station ponds). Dashed lines represent permanent or intermittent water flows. Double lanes represent paved roads. All ponds and buildings are joined by unpaved roads. Enclosed buildings are represented by grey squares. Main campus facilities (VS: School of Veterinary Medicine; WL: our on-campus

facility) are located $\sim 10 \mathrm{~km}$ south of the lower station

ease widely spread throughout the EWSFC and affected the genetics unit (GL), research buildings (RB), and ponds nearby the hatchery (F-ponds). In addition, fish maintained in our wet lab located on main campus (WL) that were brought in from East Alabama (not produced at the EWSFC) suffered from columnaris disease and were incorporated into the study. Water samples were taken from recirculating tanks with active columnaris infections.

\section{Bacterial isolation}

In total, 102 isolates of $F$. columnare (Table 1) were recovered from 4 different fish species, egg masses, and water samples during high-mortality columnaris outbreaks. Bacteria were recovered from external 
Table 1. List of all 102 Flavobacterium columnare isolates included in the study with isolate names, fish host, site of isolation, and date of isolation. CC: channel catfish; BC: blue catfish; HC: hybrid catfish; TL: tilapia; LB: largemouth bass; BG: bluegill; SpCC: spawning channel catfish; S: skin; G, gill; E: eggs; F: fry; W: water; LS: lower station; HA: hatchery; VS: veterinary school; GL: genetics laboratory; S1-11 upper station ponds; RB: research buildings at the EWSFC; RW: raceways; WL: on-campus wet laboratory; F-ponds: ponds nearby the hatchery

\begin{tabular}{|lcccc|}
\hline Isolate name & No. of isolates & Source & Site & Date \\
\hline CC-S 25 & 1 & Channel catfish & LS & 2010 \\
CC-G & 1 & Channel catfish & LS & 2010 \\
TL-S 1-3 & 3 & Tilapia & LS & 2010 \\
TL-G & 1 & Tilapia & LS & 2010 \\
CC-E 2-6,9 & 6 & Egg masses & HA & 2011 \\
CC-W 1-6 & 6 & Water & HA & 2011 \\
CC-F 2,4-7 & 5 & Channel catfish & VS & 2011 \\
BG-S 1-2, 15-22 & 10 & Bluegill & S6 & 2012 \\
BG-S 3-10 & 8 & Bluegill & S3 & 2012 \\
LB-S 1-2 & 2 & Largemouth bass & S1 & 2012 \\
BG-S 11-14 & 4 & Bluegill & S1 & 2012 \\
LB-S 3-4 & 2 & Largemouth bass & S6 & 2012 \\
BC-S 1-3 & 3 & Blue catfish & GL & 2012 \\
HC-S 1-2 & 2 & Hybrid catfish & GL & 2012 \\
CC-S 1-3 & 3 & Channel catfish & GL & 2012 \\
HC-S 3-6 & 4 & Hybrid catfish & S10 & 2012 \\
SpCC-S 2-4 & 3 & Channel catfish & RB & 2012 \\
SpCC-G & 1 & Channel catfish & RB & 2012 \\
SpCC-W 1-6 & 6 & Water & RB & 2012 \\
CC-S 4-9 & 6 & Channel catfish & RW-S1 & 2012 \\
CC-S 10-14 & 5 & Channel catfish & WL & 2012 \\
BG-S 23-27 & 5 & Bluegill & WL & 2012 \\
CC-S 15-19 & 5 & Channel catfish & S11 & 2012 \\
CC-S 20-24 & 5 & Channel catfish & RW-S1 & 2012 \\
BG-S 28-32 & 5 & Bluegill & F-ponds & 2012 \\
\hline
\end{tabular}

ATC ACC TCC TTT CTA-GAG ACA$\left.3^{\prime}\right)$ and FCISRR1 (5'-TAA TYR CTA AAG ATG TTC TTT CTA CTT GTT TG-3') that recognize the $16 \mathrm{~S}-23 \mathrm{~S}$ rDNA intergenic spacer region (ISR) of the F. columnare ribosomal RNA operon. Protocols have been previously described by Welker et al. (2005).

\section{RFLP analysis of $16 \mathrm{~S}$ rRNA gene and AFLP analysis}

The 16S rRNA gene was amplified by PCR using universal primers $20 \mathrm{~F}$ (5'-AGA GTT TGA TC(A/C) TGG CTC AG-3') and 1500R (5'-CGA TCC TAC TTG CGT AG-3'), and amplicons were digested as described previously by Triyanto \& Wakabayashi (1999) and Olivares-Fuster et al. (2007b). Two previously characterized F. Columnare strains, Genomovar I strain ARS-1 and a Genomovar II strain ALG-00-530, were used as genomovar controls for the RFLP analysis. AFLP fingerprinting was carried out according to Arias et al. $(1997,2004)$. Briefly, $100 \mathrm{ng}$ of DNA was digested with TaqI and HindIII (Promega). Following digestions, corresponding adapsurfaces (i.e. skin and gills) on selective modified Shieh (MS) agar supplemented with $1 \mathrm{\mu g} \mathrm{ml}^{-1}$ tobramycin (Decostere et al. 1997) incubated at $28^{\circ} \mathrm{C}$ for $48 \mathrm{~h}$. Putative F. columnare colonies were selected based on their typical rhizoid morphology and further confirmed by species-specific PCR (see next paragraph). All bacteria isolates were stored at $-80^{\circ} \mathrm{C}$ in $20 \%$ glycerol.

\section{DNA extraction and identification of isolates}

Genomic DNA of isolated bacteria was extracted using the Qiagen DNeasy Blood and Tissue kit (Qiagen) following manufacturer's instructions for Gramnegative bacteria. Total DNA was quantified using a Nanodrop (ND-1000) spectrophotometer (Thermo Scientific; Nanodrop Technologies) and properly diluted at $20 \mathrm{ng}^{-1} \mathrm{l}^{-1}$. Isolates were confirmed as $F$. columnare by amplifying a specific $F$. columnare locus using primer pair FCISRFL (5'-TGC GGC TGG ters (Arias et al. 1998) were added and ligated to the restriction fragments using T4 DNA ligase (Promega). Two specific primers were used in these AFLP reactions to amplify the digested fragments, the oligonucleotide T000 (5'-CGA TGA GTC CTG ACC GAA-3') matching the TaqI ends and H00A matchTA- $3^{\prime}$; the selective base at the $3^{\prime}$ end is underlined). PCR and electrophoresis conditions have been previously described (Arias et al. 2004). Ten isolates were AFLP-typed in triplicate to ensure the repeatability of the method (Arias et al. 1998). Gel images were exported to Bionumerics software (v. 7.0; Applied Maths) for analysis. After conversion, normalization, and background subtraction, the levels of similarity between resulting fingerprints were calculated using the Pearson product moment correlation coefficient. Cluster analysis was computed by the unweighted pair-group method using average linkages to identify groups of similar genotypes among the collected strains. ing the HindIII ends (5'-GAC TGC GTA CCA GCT 


\section{Antibiogram}

The disc diffusion technique (Bauer et al. 1966) was used to test the antimicrobial susceptibility of each of the isolates against the 5 selected antimicrobial agents: erythromycin $15 \mu \mathrm{g}$, oxytetracycline $30 \mu \mathrm{g}$, ampicillin $10 \mu \mathrm{g}$, kanamycin $30 \mu \mathrm{g}$, and florfenicol $30 \mu \mathrm{g}$. All antimicrobials were obtained as commercial Sensi-Disc/50 disc cartridges (Becton Dickinson), except for florfenicol (Mast Diagnostics). Strains were incubated for $18 \mathrm{~h}$ at $28^{\circ} \mathrm{C}$ in MS broth under continuous shaking. Growing conditions (18 $\mathrm{h}$ cultures and vigorous shaking) facilitated the formation of uniform lawns as F. columnare rhizoid morphology could interfere with lawn formation. The optical density of the cultures was adjusted to 0.7 at $600 \mathrm{~nm}$ using an Eppendorf Biophotometer (UV spectrophotometer). An optical density of 0.7 was equivalent to ca. $10^{7}$ colony forming units (CFU) $\mathrm{ml}^{-1}$ determined by plate counts on MS agar plates. Subsequently, $0.1 \mathrm{ml}$ of each bacterial culture was uniformly distributed onto a MS agar plate. Plates were allowed to dry for $15 \mathrm{~min}$ at room temperature to eliminate excess moisture. Antibiotic discs were discharged from their cartridges and distributed evenly in a manner in which they were $15 \mathrm{~mm}$ away from the edge of the Petri dish, and the distance between the centers of 2 disks was $\geq 24 \mathrm{~mm}$ ( 5 discs on each plate). Discs were pressed gently against the agar surface to ensure contact and subsequent antibiotic diffusion. The diameters in millimeters $(\mathrm{mm})$ of the inhibition zones were measured and recorded after incubation at $28^{\circ} \mathrm{C}$ for $48 \mathrm{~h}$. The strains were separated into 3 categories (susceptible, intermediate, or resistant, respectively) based on the diameter of the zones according to manufacturer's instructions as follows: erythromycin $>21,16-20,<13$; oxytetracycline $>19,15-18,<14$; ampicillin $>17,14-16$, $<13$; kanamycin $>18,14-17$, <13; florfenicol $>19$, $15-18,<14$ (see Table 2).

\section{Statistical analysis}

An analysis of similarities (ANOSIM) was carried out (Clarke 1993) to measure the similarity between the clusters identified by AFLP. Significant differences between sites, sources, and dates of isolation were determined using ANOSIM, testing the hypothesis that isolates from the same site, source, or date of isolation are more similar to each other than to those from different origins.

\section{RESULTS}

\section{Identification of bacterial isolates and genomovar ascription}

Of 110 putative Flavobacterium columnare isolates identified based on colony morphology on MS medium, 102 isolates (Table 1) were confirmed as $F$. columnare by species-specific PCR. All tested isolates yielded the same RFLP pattern, identical to that of Genomovar II strain ALG-00-530. Accordingly, all 102 F. columnare isolates were ascribed to Genomovar II.

\section{Genetic diversity of $\boldsymbol{F}$. columnare Genomovar II}

Fig. 2 shows the results of AFLP fingerprint cluster analysis. AFLP produced isolate-specific patterns consisting of 45 to 65 distinct bands ranging from 50 to $700 \mathrm{bp}$. Of the $102 \mathrm{AFLP}$ profiles generated from the recovered isolates, we defined 17 different profiles at $90 \%$ similarity (cut-off value for defining unique AFLP profiles was previously defined at $97 \%$ [Arias et al. 1998]; a more conservative $90 \%$ cut-off value was used to ensure that the intraspecies diversity of $F$. columnare was not overestimated). Clusters 1 to 3 comprised 2011 isolates recovered from egg masses at the HA and from fry derived from those egg masses but hatched at the VS after disinfection. Clusters 4 and 5 contained all isolates recovered from Pond S10, which had been stocked with hybrid catfish fingerlings in 2012. Cluster 6 was the largest cluster, with 27 isolates (24 from 2012 and 3 from 2011) from bluegill and catfish species from different locations. Similarly, Clusters 7 to 9 grouped 2012 isolates from bluegill, largemouth bass, and catfish species from ponds, the GL, and the RB. Profiles 10 and 11 were represented by only 1 isolate each, 1 bluegill (Profile 10) and 1 channel catfish broodstock (Profile 11), with a shared similarity of $89 \%$; both isolates were recovered from close proximity but different environments (Profile 11: open pond; Profile 10: closed recirculating system). Profile 12 was shared by 2 bluegill isolates from Pond S6. Profiles 13, 14, and 16 grouped all 2012 isolates recovered from channel catfish and bluegill fingerlings transferred from East Alabama that were housed in our WL. These clusters, along with Cluster 17 which grouped all 2012 isolates from Pond S11, were notably different from Profiles 1 to 12 , with a shared similarity of $74 \%$. Finally, Cluster 17 was the most dissimilar group and included all 2012 isolates recovered from channel catfish in Pond S11. Cluster/Profile 15 grouped all the isolates from 
\% Similarity

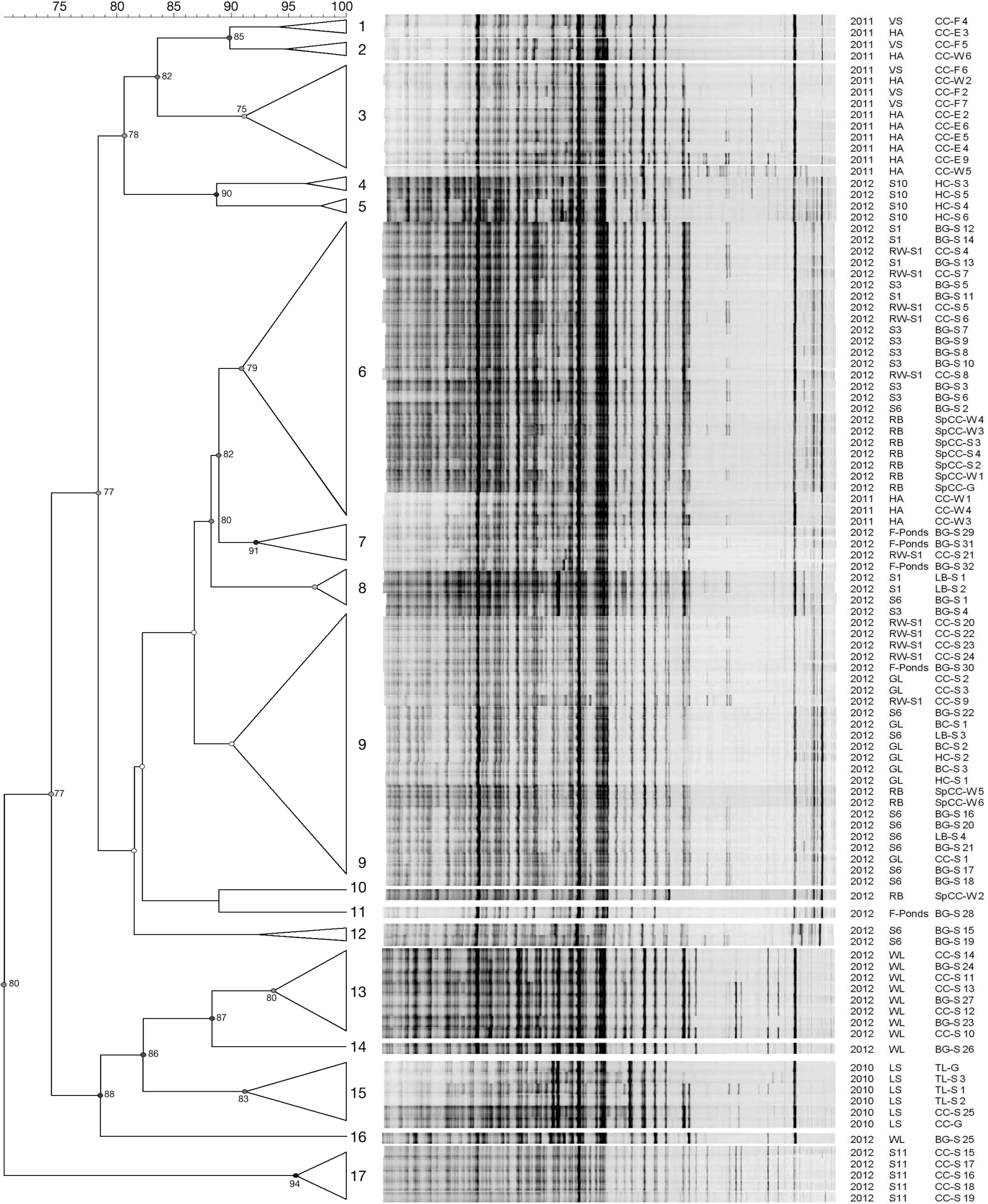


Fig. 2. Cluster analysis (unweighted pair-group method using average linkages) of the AFLP profiles of 102 Flavobacterium columnare isolates. Linkage levels are expressed as percentage similarity based on the Pearson correlation coefficient. Unique AFLP clusters were defined at $90 \%$ similarity. See Table 1 for abbreviations

2010 which were obtained from tilapia and catfish at the LS.

ANOSIM was used to directly compare groups based on site, source, and date of isolation. Our isolates clustered significantly $(\mathrm{p}=0.001)$ by the 3 factors considered (site, source, and date). However, the least influential factor was source (fish species, egg masses, or water samples) with an $\mathrm{R}$ value of 0.166 and with 14 of 50 pairwise comparisons not being significant. The $\mathrm{R}$ values for site and date were 0.671 and 0.424 , respectively. By site, 66 of 72 pairwise comparisons were significant, while by date, all the pairwise tests were significant. These $\mathrm{R}$ values indicate that groups defined by AFLP could be significantly correlated with all 3 factors, but site played the main determinant role. Fig. 3

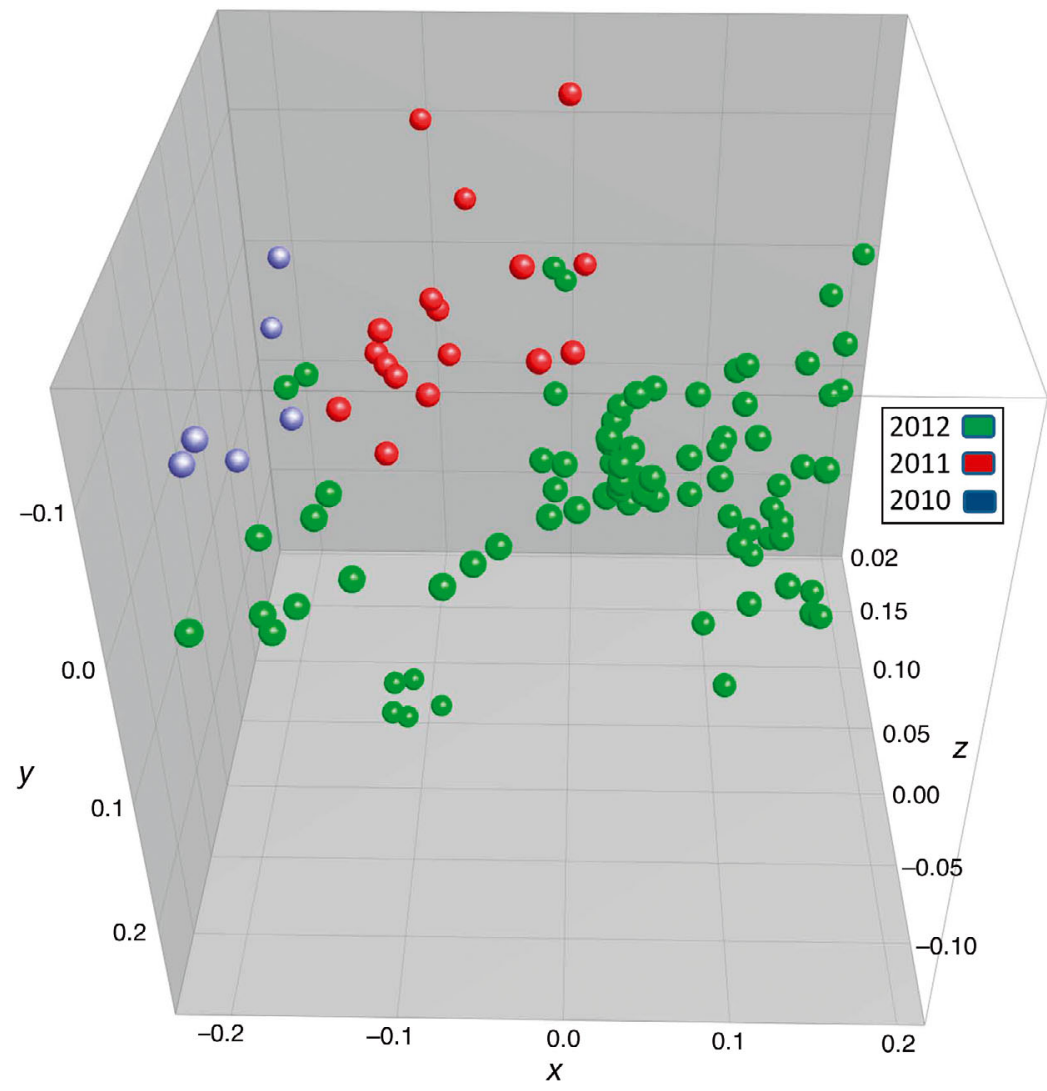

Fig. 3. Multidimensional scaling plot of the similarity matrix obtained by comparing AFLP fingerprints of all the recovered $F$. columnare isolates from 2010, 2011, and 2012. Distance between entries represents graphical dissimilarities obtained from the similarity matrix shows a multidimensional scaling analysis of the similarities obtained by AFLP analysis. Three distinct groups were evident based on date of isolation and confirmed the common origin of isolates in each year with outbreaks.

Table 2 shows the results from the antibiogram study. Among all tested isolates $(\mathrm{n}=102)$, none were resistant to florfenicol, erythromycin, and ampicillin. Resistance to oxytetracycline was detected in 19.6\% of the isolates, and $12.7 \%$ of the isolates were resistant to kanamycin. Interestingly, 2 strains (1 from skin and 1 from gill) from the same fish showed different susceptibilities towards oxytetracycline, indicating columnaris disease was caused by $>1$ strain. Also noteworthy, isolates recovered from eggs and from catfish fry immediately after hatching were resistant to oxytetracycline. However, isolates from water samples collected from the tanks in which the eggs were maintained showed a combination of resistance/susceptibility to oxytetracycline (some strains were resistant, but others were susceptible).

\section{DISCUSSION}

This study confirmed that Flavobacterium columnare Genomovar II strains are responsible for severe columnaris disease outbreaks that can become recurrent within the same watershed. In addition, our data showed Genomovar II is capable of causing very high mortalities in other fish species rarely affected by this pathogen. Olivares-Fuster et al. (2007a) showed that, in Alabama, both Genomovars I and II coexisted in the natural environment. However, in that study, the authors found an interesting host-genomovar association between Genomovar II and catfishes, while Genomovar I was predominantly recovered from threadfin shad. In salmonids, Genomovar I seems to be the predominant causative agent of columnaris disease; however, experimental infections revealed Genomovar II is indeed more virulent for 

criteria for interpretation of inhibition zones, and percentage of isolates in each class of susceptibility (resistant: $R_{i}$ intermediate: $I_{i}$ susceptible: S). Number of isolates $(n)=102$

\begin{tabular}{|lccccccc|}
\hline \multirow{2}{*}{$\begin{array}{c}\text { Antibiotic } \\
\text { (concentration) }\end{array}$} & \multicolumn{3}{c}{ Inhibition diameter $(\mathrm{mm})$} & \multicolumn{3}{c|}{ Resistant strains (\% total) } \\
& $\mathrm{R}$ & $\mathrm{I}$ & $\mathrm{S}$ & $\mathrm{R}$ & $\mathrm{I}$ & $\mathrm{S}$ \\
\hline Erythromycin $(15 \mu \mathrm{g})$ & $<13$ & $16-20$ & $>21$ & 0 & 1 & 99 \\
Oxytetracycline $(30 \mu \mathrm{g})$ & $<14$ & $15-18$ & $>19$ & 19.6 & 1 & 79.4 \\
Ampicillin $(10 \mu \mathrm{g})$ & $<13$ & $14-16$ & $>17$ & 0 & 0 & 100 \\
Kanamycin $(30 \mu \mathrm{g})$ & $<13$ & $14-17$ & $>18$ & 12.7 & 86.3 & 1 \\
Florfenicol $(30 \mu \mathrm{g})$ & $<14$ & $15-18$ & $>19$ & 0 & 0 & 100 \\
\hline
\end{tabular}

Table 2. Antimicrobial agents used in the study: compound concentrations (per disc),

ingly, 20 isolates were resistant to oxytetracycline as this antibiotic is one of the most commonly used tetracyclines for the treatment of fish bacterial diseases globally (Rigos \& Troisi 2005). Several studies have revealed tetracycline resistance in other fish pathogens, such as Aeromonas spp. and Vibrio spp. (Verner-Jeffreys et al. 2009, Č́źzek et al. 2010, Weir et al. rainbow trout than Genomovar I (Triyanto \& Wakabayashi 1999, Schneck \& Caslake 2006, Suomalainen et al. 2006, Avendano-Herrera et al. 2011, LaFrentz et al. 2012). Our data supports the hypothesis that posits Genomovar II as the most virulent type of columnaris disease regardless of the host.

Although all F. columnare isolates were Genomovar II, AFLP fingerprinting provided strain-specific profiles, since the technique screens the whole genome and depicts chromosomal polymorphisms among the isolates (Kokotovic et al. 2000). In many instances (e.g. Clusters 6 and 9), isolates recovered from different fish species, whether reared together or at different facilities, shared the same AFLP profile, suggesting that some Genomovar II types were widely spread throughout the station. This lack of host specificity at the strain level has been previously reported in Genomovar II (Arias et al. 2004). Not surprisingly, source of isolation was the least significant variable in the study, while site was the most significant one, suggesting that some strains were simultaneously introduced at different facilities. Isolates recovered in 2010 and 2011 clustered apart from those recovered in 2012, with just a few exceptions. This pattern indicates that related strains were responsible for annual outbreaks, also suggesting a successive introduction of strains into the watershed. Several factors can contribute to the introduction of $F$. columnare at different sites within the EWSFC. The exchange of fish fry or fingerlings between ponds including routine stocking of fish produced by commercial hatcheries outside the EWSFC, use of seining or fishing equipment, water flows that connect many ponds, and presence of wildlife and birds that feed on the fish could contribute to the spread of strains between different ponds at the experiment station.

Until recently, not much was known about the antimicrobial susceptibility patterns of $F$. columnare strains. In the present study, $99 \%$ of isolates were susceptible to erythromycin, while all isolates were sensitive to ampicillin and florfenicol. Not surpris-
2012). However, earlier studies showed no resistance of $F$. columnare strains to oxytetracycline (ThomasJinu \& Goodwin 2004a,b, Suomalainen et al. 2006), and not until recently was resistance of $F$. columnare toward oxytetracycline reported (Declercq et al. 2013a). Eight Finnish F. columnare strains were susceptible to ampicillin, erythromycin, and florfenicol (Suomalainen et al. 2006). Our study also reported resistance of $13 \mathrm{~F}$. columnare isolates toward kanamycin. Similarly, Bernardet \& Grimont (1989) reported $0 \mathrm{~mm}$ disk diffusion zones around kanamycin $(30 \mu \mathrm{g})$.

Nowadays, florfenicol is widely used for treatment of fish diseases in aquaculture (Aoki 2000, Sapkota et al. 2008) and is currently approved for aquaculture purposes in 25 countries (Gaunt et al. 2010). Florfenicol is approved by the FDA for the treatment of coldwater disease and furunculosis in salmonids as well as of enteric septicaemia and columnaris disease in catfishes (www.fda.gov/AnimalVeterinary/Development ApprovalProcess/Aquaculture/ucm132954.htm, accessed 2011). In this study, none of the F. columnare isolates displayed resistance toward florfenicol; likewise, susceptibility of F. columnare to this antibiotic has been reported elsewhere (Suomalainen et al. 2006, Gaunt et al. 2010). During our study, only catfish raised in F-ponds, LS ponds, and raceways received florfenicol-supplement diets (AQUAFLOR ${ }^{\circledR}$, Merck) but medicated feed is routinely used at the EWSFC during disease outbreaks.

The existence of several genotypes in disease outbreaks has been previously documented in F. columnare (Triyanto et al. 1999, Suomalainen et al. 2006) and F. psychrophilum (Madetoja et al. 2001). However, co-infection by $>1$ strain in the same fish is rarely documented. In this study, we isolated $2 \mathrm{~F}$. columnare strains from a single infected fish which differed in their antibiotic susceptibility pattern despite sharing the same AFLP profile. The coexistence of $>1$ strain in the fish may be due to the ubiquitous distribution of $F$. columnare in aquatic environments and the lack of host-specificity observed 
within Genomovar II strains. In addition, we observed a trend associated with oxytetracycline resistance in the isolates from the egg masses, catfish fry, and water samples. F. columnare isolates from the egg masses and from the catfish fry that hatched from these egg masses were resistant to oxytetracycline. However, water samples from the same tanks contained both oxytetracycline-resistant and oxytetracycline-susceptible isolates. It is plausible that the resistance to oxytetracycline changes the adhesion properties of the $F$. columnare cell membranes, thus facilitating attachment to eggs. This hypothesis is supported by the close genetic relationship observed among egg and fry isolates (AFLP Types 1 to 3). The possible effect of iodine disinfection in strain selection warrants further investigation.

In conclusion, Genomovar II strains of F. columnare were responsible for the severe columnaris outbreaks affecting the EWSFC from 2010 to 2012. We confirmed that Genomovar II of $F$. columnare is the prevalent genomovar in aquaculture and sport fishing ponds during columnaris outbreaks in our experiment station. Genomovar II strains showed a marked genetic diversity among themselves, but strain relatedness was primarily influenced by date and site of isolation, suggesting periodic introductions of new strains into the watershed and simultaneous introductions at different facilities within the watershed. According to the results of the present study, resistance to florfenicol has not yet developed in our facilities, and florfenicol remains the drug of choice for treatment of fish during columnaris outbreaks.

Acknowledgements. We thank Dr. Joseph C. Newton (College of Veterinary Medicine, Auburn University) for maintaining channel catfish fry. We also thank Dr. Ronald P. Phelps, Russell Wright, and Eric Peatman (Dept. of Fisheries and Allied Aquacultures, Auburn University) for providing egg masses, catfishes, and alerting us of ongoing outbreaks in sport fishing ponds. We thank the management team of the E. W. Shell Fisheries Center, North Auburn research station, for their support. We also thank Andrea Larsen for statistical help and Candis Ray for editing the manuscript. H.H.M. thanks the Egyptian Cultural and Educational Bureau (ECEB) in Washington, DC, for funding his graduate research scholarship. This research was funded by the USDA-ARS/Auburn University Specific Cooperative Agreement 'Prevention of Diseases of Farmed Raised Fish' and USDA-ARS CRIS Project No. 6420-32000-022-00D.

\section{LITERATURE CITED}

Aoki T (2000) Transferable drug resistance plasmids in fishpathogenic bacteria. In: Arthur JR, Lavilla-Pitogo CR, Subasinghe RP (eds) Proc Meet Use of Chemicals in Aquaculture in Asia, 20-22 May 1996, Tigbauan, Iloilo,
Philippines. Aquaculture Department, SEAFDEC, Tigbauan, p 31-33

Arias CR, Verdonck L, Swings J, Garay E, Aznar R (1997) Intraspecific differentiation of Vibrio vulnificus biotypes by amplified fragment length polymorphism and ribotyping. Appl Environ Microbiol 63:2600-2606

Arias CR, Pujalte MJ, Garay E, Aznar R (1998) Genetic relatedness among environmental, clinical, and diseased-eel Vibrio vulnificus isolates from different geographic regions by ribotyping and randomly amplified polymorphic DNA PCR. Appl Environ Microbiol 64:3403-3410

Arias CR, Welker TL, Shoemaker CA, Abernathy JW, Klesius PH (2004) Genetic fingerprinting of Flavobacterium columnare isolates from cultured fish. J Appl Microbiol 97:421-428

Arias CR, Cai W, Peatman E, Bullard SA (2012) Catfish hybrid Ictalurus punctatus $\times I$. furcatus exhibits higher resistance to columnaris disease than the parental species. Dis Aquat Org 100:77-81

Austin B, Austin DA (1999) Bacterial fish pathogens: diseases of farmed and wild fish, 3rd edn. Springer-Praxis, Chichester

Avendano-Herrera R, Gherardelli V, Olmos P, Godoy MG, Heisinger A, Fernandez J (2011) Flavobacterium columnare associated with mortality of salmonids farmed in Chile: a case report of two outbreaks. Bull Eur Assoc Fish Pathol 31:36-44

Bader JA, Nusbaum KE, Shoemaker CA (2003) Comparative challenge model of Flavobacterium columnare using abraded and unabraded channel catfish, Ictalurus punctatus (Rafinesque). J Fish Dis 26:461-467

Bader JA, Moore SA, Nusbaum KE (2006) The effect of cutaneous injury on a reproducible immersion challenge model for Flavobacterium columnare infection in channel catfish (Ictalurus punctatus). Aquaculture 253:1-9

Bauer AW, Kirby WM, Sherris JC, Turck M (1966) Antibiotic susceptibility testing by a standardized single disk method. Am J Clin Pathol 45:493-496

Bernardet JF, Grimont PA (1989) Deoxyribonucleic acid relatedness and phenotypic characterization of Flexibacter columnaris sp. nov., nom. rev., Flexibacter psychrophilus sp. nov., nom. rev., and Flexibacter maritimus Wakabayashi, Hikida, and Masumura 1986. Int J Syst Evol Microbiol 39:346-354

Čížek A, Dolejská M, Sochorová R, Strachotová K, Piačková $\mathrm{V}$, Veselý T (2010) Antimicrobial resistance and its genetic determinants in aeromonads isolated in ornamental (koi) carp (Cyprinus carpio koi) and common carp (Cyprinus carpio). Vet Microbiol 142:435-439

> Clarke KR (1993) Non-parametric multivariate analyses of changes in community structure. Aust J Ecol 18:117-143

Darwish AM, Ismaiel AA (2005) Genetic diversity of Flavobacterium columnare examined by restriction fragment length polymorphism and sequencing of the $16 \mathrm{~S}$ ribosomal RNA gene and the 16S-23S rDNA spacer. Mol Cell Probes 19:267-274

> Declercq AM, Boyen F, Van den Broeck W, Bossier P, Karsi A, Haesebrouck F, Decostere A (2013a) Antimicrobial susceptibility pattern of Flavobacterium columnare isolates collected worldwide from 17 fish species. J Fish Dis 36:45-55

Declercq AM, Haesebrouck F, Van den Broeck W, Bossier P, Decostere A (2013b) Columnaris disease in fish: a review with emphasis on bacterium-host interactions. Vet Res $44: 27$ 
Decostere A (2002) Flavobacterium columnare infections in fish: the agent and its adhesion to the gill tissue. Verh K Acad Geneeskd Belg 64:421-430

> Decostere A, Haesebrouck F, Devriese LA (1997) Shieh medium supplemented with tobramycin for selective isolation of Flavobacterium columnare (Flexibacter columnaris) from diseased fish. J Clin Microbiol 35:322-324

> Decostere A, Haesebrouck F, Turnbull J, Charlier G (1999) Influence of water quality and temperature on adhesion of high and low virulence Flavobacterium columnare strains to isolated gill arches. J Fish Dis 22:1-11

Ekman E (2003) Natural and experimental infections with Flavobacterium psychrophilum in salmonid fish. Doctoral thesis, Swedish University of Agricultural Sciences, Uppsala

Farmer B (2004) Improved methods for the isolation and characterization of Flavobacterium columnare. MS thesis, Louisiana State University, Baton Rouge, LA

Gaunt PS, Gao DN, Sun FS, Endris R (2010) Efficacy of florfenicol for control of mortality caused by Flavobacterium columnare infection in channel catfish. J Aquat Anim Health 22:115-122

> Iguchi K, Ogawa K, Nagae M, Ito F (2003) The influence of rearing density on stress response and disease susceptibility of ayu (Plecoglossus altivelis). Aquaculture 220: 515-523

> Kokotovic B, Bölske G, Ahrens P, Johansson KE (2000) Genomic variations of Mycoplasma capricolum subsp. capripneumoniae detected by amplified fragment length polymorphism (AFLP) analysis. FEMS Microbiol Lett 184:63-68

> LaFrentz BR, LaPatra SE, Shoemaker CA, Klesius PH (2012) Reproducible challenge model to investigate the virulence of Flavobacterium columnare genomovars in rainbow trout Oncorhynchus mykiss. Dis Aquat Org 101:115-122

LaFrentz B, Waldbieser G, Welch T, Shoemaker C (2013) Intragenomic heterogeneity in the 16S rRNA genes of Flavobacterium columnare and standard protocol for genomovar assignment. J Fish Dis 37:657-669

Madetoja J, Hänninen ML, Hirvelä-Koski V, Dalsgaard I, Wiklund T (2001) Phenotypic and genotypic characterization of Flavobacterium psychrophilum from Finnish fish farms. J Fish Dis 24:469-479

Miranda CD, Rojas R (2007) Occurrence of florfenicol resistance in bacteria associated with two Chilean salmon farms with different history of antibacterial usage. Aquaculture 266:39-46

> Miyashita NT, Kawabe A, Innan H (1999) DNA variation in the wild plant Arabidopsis thaliana revealed by amplified fragment length polymorphism analysis. Genetics 152:1723-1731

MSU (2010) 2010 annual case summary report of the Aquatic Research and Diagnostic Laboratory. Mississippi State University, Stoneville, MS, available at http:// tcnwac.msstate.edu//cvm2010.pdf

MSU (2012) 2012 annual case summary report of the Aquatic Research and Diagnostic Laboratory. Mississippi State University, Stoneville, MS, available at http:// tcnwac.msstate.edu/cvm2012.pdf

> Olivares-Fuster O, Baker JL, Terhune JS, Shoemaker CA, Klesius PH, Arias CR (2007a) Host-specific association between Flavobacterium columnare genomovars and fish species. Syst Appl Microbiol 30:624-633

> Olivares-Fuster O, Shoemaker CA, Klesius PH, Arias CR (2007b) Molecular typing of isolates of the fish pathogen,
Flavobacterium columnare, by single-strand conformation polymorphism analysis. FEMS Microbiol Lett 269: 63-69

Olivares-Fuster O, Bullard SA, McElwain A, Llosa MJ, Arias CR (2011) Adhesion dynamics of Flavobacterium columnare to channel catfish Ictalurus punctatus and zebrafish Danio rerio after immersion challenge. Dis Aquat Org 96: 221-227

Plumb JA (1999) Health maintenance and principal microbial diseases of cultured fishes. Iowa State University Press, Ames, IA

> Rigos G, Troisi G (2005) Antibacterial agents in Mediterranean finfish farming: a synopsis of drug pharmacokinetics in important euryhaline fish species and possible environmental implications. Rev Fish Biol Fish 15:53-73

Sapkota A, Sapkota AR, Kucharski M, Burke J, McKenzie S, Walker P, Lawrence R (2008) Aquaculture practices and potential human health risks: current knowledge and future priorities. Environ Int 34:1215-1226

Schmidt AS, Bruun MS, Dalsgaard I, Pedersen K, Larsen JL (2000) Occurrence of antimicrobial resistance in fishpathogenic and environmental bacteria associated with four Danish rainbow trout farms. Appl Environ Microbiol 66:4908-4915

Schneck JL, Caslake LF (2006) Genetic diversity of Flavobacterium columnare isolated from fish collected from warm and cold water. J Fish Dis 29:245-248

Serrano PH (2005) Responsible use of antibiotics in aquaculture. FAO Fish Tech Pap No. 469. FAO, Rome

Shoemaker CA, Klesius PH, Lim C, Yildirim M (2003) Feed deprivation of channel catfish, Ictalurus punctatus (Rafinesque), influences organosomatic indices, chemical composition and susceptibility to Flavobacterium columnare. J Fish Dis 26:553-561

Shoemaker CA, Olivares-Fuster O, Arias CR, Klesius PH (2008) Flavobacterium columnare genomovar influences mortality in channel catfish (Ictalurus punctatus). Vet Microbiol 127:353-359

Soto E, Mauel M, Karsi A, Lawrence M (2008) Genetic and virulence characterization of Flavobacterium columnare from channel catfish (Ictalurus punctatus). J Appl Microbiol 104:1302-1310

Suomalainen LR (2005) Flavobacterium columnare in Finnish fish farming: characterisation and putative disease management strategies. University of Jyväskylä

> Suomalainen LR, Tiirola M, Valtonen E (2005) Influence of rearing conditions on Flavobacterium columnare infection of rainbow trout, Oncorhynchus mykiss (Walbaum). J Fish Dis 28:271-277

> Suomalainen LR, Kunttu H, Valtonen ET, Hirvelä-Koski V, Tiirola M (2006) Molecular diversity and growth features of Flavobacterium columnare strains isolated in Finland. Dis Aquat Org 70:55-61

Suomalainen LR, Bandilla M, Valtonen ET (2009) Immunostimulants in prevention of columnaris disease of rainbow trout, Oncorhynchus mykiss (Walbaum). J Fish Dis 32: 723-726

Thoesen JC (2004) Suggested procedures for the detection and identification of certain finfish and shellfish pathogens. American Fisheries Society-Fish Health Section, Bethesda, MD

Thomas-Jinu S, Goodwin A (2004a) Acute columnaris infection in channel catfish, Ictalurus punctatus (Rafinesque): efficacy of practical treatments for warmwater aquaculture ponds. J Fish Dis 27:23-28 
Thomas-Jinu S, Goodwin A (2004b) Morphological and genetic characteristics of Flavobacterium columnare isolates: correlations with virulence in fish. J Fish Dis 27: 29-35

- Triyanto, Kumamaru A, Wakabayashi H (1999) The use of PCR targeted 16S rDNA for identification of genomovars of Flavobacterium columnare. Fish Pathol 34:217-218

Triyanto A, Wakabayashi H (1999) Genotypic diversity of strains of Flavobacterium columnare from diseased fishes. Fish Pathol 34:65-71

Verner-Jeffreys DW, Welch TJ, Schwarz T, Pond MJ and others (2009) High prevalence of multidrug-tolerant bacteria and associated antimicrobial resistance genes isolated from ornamental fish and their carriage water.

Editorial responsibility: Catherine Collins, Aberdeen, UK
PLoS ONE 4:e8388

> Wakabayashi H (1991) Effect of environmental conditions on the infectivity of Flexibacter columnaris to fish. J Fish Dis 14:279-290

Weir M, Rajić A, Dutil L, Cernicchiaro N, Uhland F, Mercier B, Tuševljak N (2012) Zoonotic bacteria, antimicrobial use and antimicrobial resistance in ornamental fish: a systematic review of the existing research and survey of aquaculture-allied professionals. Epidemiol Infect 140: 192-206

Welker TL, Shoemaker CA, Arias CR, Klesius PH (2005) Transmission and detection of Flavobacterium columnare in channel catfish Ictalurus punctatus. Dis Aquat Org 63:129-138

Submitted: August 15, 2013; Accepted: March 1, 2014 Proofs received from author(s): May 27, 2014 